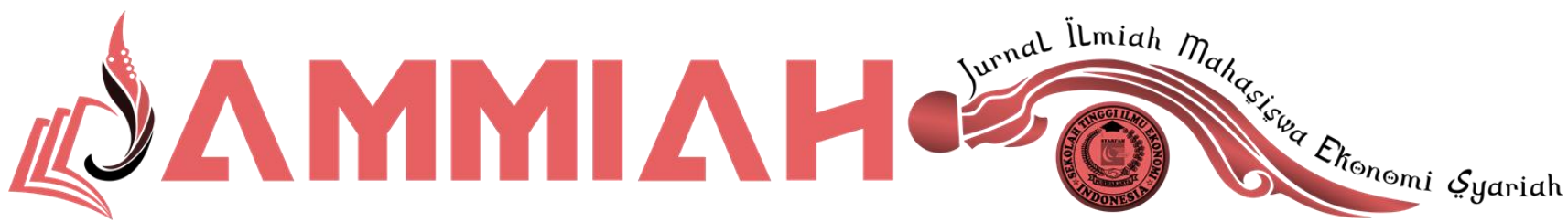 \\ Volume 1 Nomor 1, Maret 2021 \\ DOI: https://doi.org/10.37726/
}

\section{Penanganan Nasabah Menunggak Kartu Kredit Kolektibilitas Lima Di PT. Muara Toba Persada Bandung}

\author{
Yunita Widiyaningrum \\ Sekolah Tinggi Ilmu Ekonomi Syariah (STIES) Indonesia Purwakarta \\ yunitawidiyaningrum@ggmail.com
}

\begin{abstract}
ABSTRAK
Tujuan penelitian ini untuk mengetahui penanganan nasabah kartu kredit, dan untuk mengetahui cara pembayaran kartu kredit. Dalam penanganan deskcall terhadap nasabah harus melakukan pencarian data terbaru dikarnakan data yang diberikan perusahaan rata-rata data yang sudah pernah dikelola oleh bank. Faktor yang menyebabkan nasabah masuk kolektibilitas lima di PT. Muara Toba Persada yaitu karena tidak adanya itikad baik dari pemegang kartu kredit, karena adanya kebutuhan lain yang mendesak, dan karena pemegang kartu kredit di PHK. Selanjutnya mengenai penanganan Kartu kredit yang sudah masuk kolektabilitas lima di PT. Muara Toba Persada adalah dengan melakukan negosiasi tagihan kartu kredit melalui Telepon, Surat Peringatan (Letter), Kunjungan (Visit). Jika upaya hukum non litigasi tersebut tidak dapat terlaksana dengan baik, maka pihak bank dapat menempuh upaya hukum litigasi penyelesaian sengketa melalui jalur pengadilan, akan tetapi hal ini tidak dilakukan, mengingat jumlah tagihan kartu kreditnya lebih sedikit daripada jumlah pengeluaran yang dilakukan untuk melakukan menyelesaian sengketa melalui jalur pengadilan. Dalam menggunakan kartu kredit sebaiknya pemegang kartu kredit harus lebih cermat dalam melunasi tagihan kartu kreditnya dengan memenuhi ketentuan yang telah diperjanjikan sebelumnya, sehingga tidak timbulnya tagihan kartu kredit wanprestasi, dan untuk pihak PT Bank Mandiri (Persero) Tbk. Gajah Mada Denpasar selaku penerbit kartu
\end{abstract}

JAMMIAH (Jurnal Ilmiah Mahasiswa Ekonomi Syariah), Volume 1, Nomor 1, Maret 2021

http://journal.sties-purwakarta.ac.id/index.php/jammiah/

ISSN: xxxx-xxxx (Media Online) xxxx-xxxx (Media Cetak) 
kredit sebaiknya lebih meningkatkan kinerjanya dalam melakukan analisa terhadap calon pemegang kartu kredit, tidak hanya semata-mata mencari keuntungan yang nantinya hanya akan menimbulkan kartu kredit wanprestasi di kemudian hari. Adapun cara pembayaran yang bisa nasabah gunakan dengan cara datang langsung ke kantor BRI terdekat atau dengan cara di transfer menggunakan atm BRI terdekat, dengan cara : Pilih menu transaksi lain, pilih menu pembayaran, pilih menu kartu kredit, pilih menu BRI, masukkan 16 angka nomor kartu kredit, pilih YA pada menu untuk melanjutkan transaksi, masukkan jumlah pembayaran yang sudah ada, pilih YA, pada menu konfirmasi pembayaran.

Kata Kunci : Penanganan Nasabah Menunggak, Pembayaran Kartu Kredit Kolektibilitas Lima.

\section{ABSTRACT}

The purpose of this study is to determine the handling of credit card customers, and to find out how credit card payments. In handling deskcall, customers must search for the latest data because the data provided by the company is on average data that has been managed by the bank. Factors that cause customers to enter the collectability of five at PT. Muara Toba Persada, namely because of the lack of goodwill from the credit card holder, because of other urgent needs, and because the credit card holder was laid off. Furthermore, regarding the handling of credit cards that have entered the collectability of five at PT. Muara Toba Persada is by negotiating credit card bills by telephone, warning letters (letters), visits (visit). If the non-litigation legal action cannot be carried out properly, then the bank can take legal action to resolve the dispute through court channels, but this is not done, considering that the amount of credit card bills is less than the amount spent to resolve the dispute through court route. In using a credit card, credit card holders should be more careful in paying off their credit card bills by fulfilling the conditions previously agreed, so that credit card bills are not in default, and for PT Bank Mandiri (Persero) Tbk. Gajah Mada Denpasar as the credit card issuer should further improve its performance in analyzing prospective credit card holders, not just looking for profits which will only lead to credit card defaults in the future. There are payment methods that customers can use by coming directly to the nearest BRI office or by transferring using the nearest BRI ATM, by: Select another transaction menu, select the payment menu, select the credit card menu, select the BRI menu, enter the 16 digit number credit card, select YES on the menu to continue the transaction, enter the existing payment amount, select YES, on the payment confirmation menu.

Keywords: Handling delinquent customers, collectability credit card payments five.

JAMMIAH (Jurnal Ilmiah Mahasiswa Ekonomi Syariah), Volume 1, Nomor 1, Maret 2021

http://journal.sties-purwakarta.ac.id/index.php/jammiah/

ISSN: xxxx-xxxx (Media Online) xxxx-xxxx (Media Cetak) 


\section{PENDAHULUAN}

Dalam kehidupan sehari-hari, kata kredit bukan merupakan perkataan asing bagi masyarakat. Perkataan kredit tidak saja dikenal oleh masyarakat-masyarakat di kota-kota besar, tetapi sampai di desa-desa pun kata kredit tersebut sudah sangat popular. Istilah kredit berasal dari bahasa Yunani (credere) yang berarti kepercayaan (truth atau faith), oleh karena itu dasar kredit adalah kepercayaan. Kredit dapat didefinisikan sebagai fasilitas yang akan disalurkan kepada pihak lain yang membutuhkan dana dengan atas dasar kesepakatan dan persetujuan bersama untuk melunasi kewajibannya dengan jangka waktu tertentu dengan meliputi pokok pinjaman, bunga, imbalan maupun secara bagi hasil keuntungan ${ }^{1}$.

Kartu kredit (credit card) dalam bahasa Arab disebut bithaqah i'timan. Secara bahasa kata bithaqah (kartu) digunakan untuk potongan kertas kecil atau dari bahan lain yang di atasnya ditulis penjelasan yang berkaitan dengan potongan kertas itu, sementara kata i'timan secara bahasa artinya adalah kondisi aman dan saling percaya. Dalam kebiasaan dalam dunia usaha artinya semacam pinjaman, yakni yang berasal dari kepercayaan terhadap peminjam dan sikap amanahnya serta kejujurannya. Oleh sebab itu ia memberikan dana itu dalam bentuk pinjaman untuk dibayar secara tertunda ${ }^{2}$.

Kartu kredit terdiri dari dua kata yaitu kartu dan kredit. Kartu adalah kertas tebal yang Selanjutnya membebankan kewajiban kepada penerbit kartu kredit untuk melunasi harga barang dan jasa. Kemudian kepada penerbitnya diberikan hak untuk menagih kembali pelunasan harga tersebut dari pihak pemegang kartu kredit plus biaya-biaya lainnya, seperti bunga, biaya tahunan, uang pangkal, dengan dan sebagainya ${ }^{3}$.

Kartu kredit bukanlah suatu alat pembayaran seperti halnya wesel dan cek karena dengan mengunakan kartu kredit sebagai pelaksanaan pembayaran tidaklah terjadi suatu pemindahan dana dari pemegang kartu kepada penerima pembayaran (dalam hal ini outlets). Kartu kredit berbeda dengan cek dan wesel, tidaklah diatur dalam undangundang dan kartu kredit tidak bisa dipindah alihkan ${ }^{4}$.

Kartu Kredit merupakan istilah yang diadopsi dari istilah credit card, merupakan kata majemuk, yang terjadi dari dua kata yang masing-masing mempunyai pengertian dan arti yang berbeda, dalam pengertian yang tidak sepadan serta berbeda pula pengertiannya secara harafiahnya ${ }^{5}$.

${ }^{1}$ Gesha Tri Winarto, Evaluasi Sistem Pemberian Dan Pelunasan Kredit Pada Koperasi Harum Desa Kunira Kecamatan Batangan Kabupaten Pati, Diss, (Universitas Sebelas Maret (UNS) Solo, 2010).

2 Setiawan Budi Utomo, Hukum Kartu Kredit Syariah, (Bandung: Rajawali Pers, 2009), 80.

3 Departemen Pendidikan dan Kebudayaan, Kamus Besar Bahasa Indonesia, (Jakarta: Departemen Pendidikan dan Kebudayaan, 1985), 395.

${ }^{4}$ Wahyu Hardjo, Kartu Kredit dalam Kaitannya dengan Sistem Pembayaran, (Jakarta: Pro Justitia, 1992$), 65$.

${ }^{5}$ Sri Redjeki Hartono, Aspek Hukum Penggunaan Kartu Kredit, (Jakarta: Badan Pembinaan Hukum Nasional, Departemen Kehakiman, 1994), 35.

JAMMIAH (Jurnal Ilmiah Mahasiswa Ekonomi Syariah), Volume 1, Nomor 1, Maret 2021 
Dapat disimpulkan bahwa kartu kredit adalah alat pembayaran untuk membeli barang atau jasa di tempat-tempat yang sudah ditentukan, dan berupa kartu plastik. Kartu kredit itu sendiri menawarkan cicilan kepada penggunanya untuk melunasi barang atau jasa konsumennya dalam jangka waktu tertentu. Tidak berapa besar biasanya persegi panjang untuk berbagai keperluan.

Peneliti (deskcall) memiliki (problem statement) yaitu mengenai penanganannya terhadap nasabah yang statusnya sudah kolektibilitas lima. Peneliti melakukan beberapa tahapan untuk menyelesaikan penanganannya dengan nasabah. Dan adapun tujuan peneliti terhadap penanganan nasabah menunggak dengan status kolektibilitas lima dengan baik dan benar.

Peneliti sudah mencapai pengetahuannya mengenai bagaimana cara penanganan terhadap beberapa nasabah yang sulit untuk menyelesaikan tunggakkannya. Beberapa hal yang peneliti dapatkan dari hasil penelitian mengenai credit card, terlebih langsung menangani banyak nasabah yang sudah lama tidak terhubung dan tidak sedikit yang lupa atau lalai dalam mebayar tunggakan kartu kreditnya. Deskcall bertugas untuk mengingatkan pembayaran kartu kredit, dan mengarahkan langsung untuk pembayaran nya ke pihak bank ${ }^{6}$.

Penelitian tentang Penanganan Nasabah Menunggak Kartu Kredit Kolektibilitas Lima sudah banyak dilakukan oleh peneliti sebelumnya seperti yang dilakukan oleh Leni Saputri. Tujuan dilakukan penelitian ini adalah untuk mengetahui penanganan pembiayaan

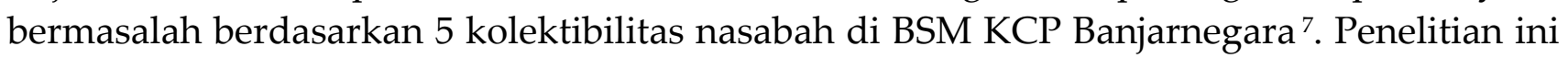
juga hanya mengkaji tentang Penanganan Nasabah Menunggak Kartu Kredit Kolektibilitas Lima diberbagai Bank.

Penelitian-penelitian sebelumnya banyak mengkaji atau meneliti tentang Penanganan Nasabah Menunggak Kartu Kredit Kolektibilitas Lima tidak sama penanganannya dengan bank lainnya. Penelitian ini mengkaji lebih dalam terkait Penanganan Nasabah Menunggak Kartu Kredit Kolektibilitas Lima termasuk strategi sistem dalam penanganan kolektibilitas lima.

Fokus penelitian ini adalah untuk mengetahui penanganan nasabah menunggak kartu kredit di PT. PT. Muara Toba Persada, dan cara pembayaran kartu kredit pada PT. Muara Toba Persada.

\section{TINJAUAN PUSTAKA}

Penelitian tentang Penanganan Nasabah Menunggak Kartu Kredit Kolektibilitas Lima sudah banyak dilakukan oleh peneliti sebelumnya seperti yang

${ }^{6}$ Mahmoedin, 100 Penyebab Kredit Macet, (Jakarta: Pustaka Sinar Harapan, 1995), 75.

${ }^{7}$ Leni Saputri, Penanganan pembiayaan bermasalah berdasarkan 5 kolektibilitas di bank syari'ah mandiri (bsm) kcp banjarnegara, Diss, (Institut Agama Islam Negeri (IAIN) Bandung, 2015).

JAMMIAH (Jurnal Ilmiah Mahasiswa Ekonomi Syariah), Volume 1, Nomor 1, Maret 2021 
dilakukan oleh Febry Ayu Ramadhani, ${ }^{8}$ Perbankan Syariah sebagai lembaga Intermediatary dimana menjadi perantara antara pihak yang mempunyai kelebihan dana (Surplus Unit) dan pihak yang mengalami kekurangan dana oleh perbankan syariah dan menyalurkan dana tersebut dalam bentuk pembiayaan. Dari penyaluran yang diberikan, pihak bank haruslah mengantisipasi dan mempunyai langkah penanganan dari adanya resiko kemacetan pembayaran angsuran yang dapat mengakibatkan pembiayaan bermasalah.

Pembiayaan Bermasalah adalah kondisi dimana nasabah tidak dapat mengembalikan pinjaman sesuai dengan waktu yang telah disepakati. Pembiayaan Bermasalah adalah risiko yang melekat pada dunia perbankan, karena bisnis utama perbankan pada dasarnya adalah menghimpun dan menyalurkan dana Dana yang terkumpul menimbulkan risiko yang di satu sisi, dana yang disalurkan sebagai pembiayaan pada dasarnya merupakan kesalahan pihak Bank ${ }^{9}$. Rasio keuangan yang digunakan untuk mengukur pembiayaan bermasalah adalah Non Performing Financing (NPF) rasio ini digunakan untuk mengukur kemampuan bank dalam meminimalkan pembiayaan bermasalah ${ }^{10}$.

Penelitian yang dilakukan peneliti sebelumnya oleh I Made Tistiawan Dwihana Putra ${ }^{11}$, kredit bermasalah/macet pada BUMDes Muncul Sari Aji terdapat dari dua sisi, yaitu : 1) Dari sisi BUMDes Muncul Sari Aji, Kelemahan analisis oleh pejabat kredit sejak awal proses pemberian kredit, Kelemahan dalam pembinaan dan monitoring kredit, 2) Dari sisi nasabah, dimana terdapat karakter yang buruk dan persepsi nasabah yang beranggapan bahwa pinjaman yang diberikan dari BUMDes Muncul Sari Aji adalah bantuan, selain itu nasabah yang menunggak membayar dikarenakan pengaruh nasabah lainnya, 3) Kondisi ekonomi nasabah yang memang berasal dari latar belakangkeluarga kurang miskin, (3) Upaya BUMDes Mucul Sari Aji dalam penanganan kredit bermasalah/macet menggunakan pendekatan persuasif dimana pendekatan persuasif ini merupakan komunikasi yang bertujuan untuk mengubah atau memengaruhi kepercayaan, sikap, dan perilaku seseorang. upaya yang dilakukan BUMDes Muncul Sari Aji belum maksimal dimana, kredit macet dengan total $\mathrm{Rp} 357.911 .000$ perbedaannya sangat jauh dengan kredit yang

${ }^{8}$ Febry Ayu Ramadhani, Analisis penanganan pembiayaan bermasalah nasabah usaha mikro: Studi kasus pada Bank Syariah Mandiri KCP Kepanjen. Diss, (Universitas Islam Negeri Maulana Malik Ibrahim, Malang, 2019).

${ }^{9}$ Edi Susilo, Analisis Pembiayaan Dan Risiko Perbankan Syariah Jilid 1, (Yogyakarta: Pustaka Pelajar, 2017), 313.

${ }^{10}$ Mahmoedin, 100 Penyebab Kredit Macet, (Jakarta: Pustaka Sinar Harapan, 1995).

${ }^{11}$ I Made Tistiawan Dwihara Putra, dkk, Analisis Sistem Penyaluran Kredit Pada Badan Usaha Milik Desa (Bumdes) Muncul Sari Aji Desa Sudaji, Kecamatan Sawan, Kabupaten Buleleng, Jurnal S1 Akuntasi Universitas Pendidikan Ganesha, Volume 8 No. 2 (2017), 9-10.

JAMMIAH (Jurnal Ilmiah Mahasiswa Ekonomi Syariah), Volume 1, Nomor 1, Maret 2021 
lancar hanya sebesar Rp 891.000 berimbuh dengan kredit dalam keadaan perhatian khusus sebesar Rp 5.310.000, Kurang lancar sebesar Rp 23.954.000, dan kredit yang kriteria diragukan sebesar Rp 493.000. Dari tabel tunggakan nasabah tahun 20132016 masih banyak terdapat kredit bermasalah dan berfluktuasi jadi pendekatan secara persuasif belum terlalu efektif.

Adapun peneliti sebelum yang dilakukan oleh Fitri Rahmawati Pramanasari Berdasarkan hasil penelitian dan pembahasan dihasilkan kesimpulan, Kesatu, proses penyelesaian wanprestasi nasabah atas tagihan kartu kredit macet dilakukan dengan penagihan melalui telepon. Proses penagihan ini dilakukan oleh karyawan bank. Namun, apabila karyawan menemukan kendala dalam penagihan lewat telepon dan jatuh tempo telah memenuhi kriteria macet, maka proses penagihannya dilakukan oleh field collector. Field collector bertugas mencari dan menemukan nasabah untuk melakukan penagihan. Kedua, hambatan-hambatan yang dihadapi adalah : nasabah yang hilang, nasabah yang pindah tempat tinggal, nasabah yang beriktikad buruk dengan memiliki ketidakmauan untuk membayar, serta nasabah yang tidak percaya kepada field collector. Cara mengatasi kartu kredit macet yaitu melakukan mekanisme BI checking, prinsip mengenal nasabah, bekerjasama dengan komunitas collection untuk tukar-menukar informasi, meningkatkan mutu sumber daya manusia yang solid dalam bidang perkreditan, meningkatkan manajemen resiko, Rescheduling (penjadwalan kembali), Reconditioning (persyaratan kembali), Retructuring (penataan kembali), Pengawasan dan Laporan Perkembangan Penyesuaian Kartu Kredit. ${ }^{12}$

\section{HASIL DAN PEMBAHASAN}

Selama penelitian yang penulis lakukan di PT. Muara Toba Persada penulis di posisikan pada bagian Desk collection. Dalam penempatan tersebut memiliki fungsi pendataan Nasabah yang berstatus kolektibilitas lima. Mencari kebenaran dan keberadaan Nasabah tersebut masih valid Datanya. Menyampaikan infomasi dan mengingatkan kepada Nasabah yang sudah Valid untuk membayarkan tunggakan sesuai dengan total tunggakan yang ada di data tersebut. Sebagai feedback Perusahaan ke Desk collection, Pihak BRI memberikan 3\% dari Total tunggakan untuk membayar gaji Desk collection.

Selain melakukan kegiatan sebagai Desk collection, penulis pun membahas pokok permasalahan, sebagai pengetahuan dan wawasan selama massa Praktik Kerja

${ }^{12}$ Fitri Rahmawati Pramanasari, Penyelesaian Wanprestasi Nasabah Atas Tagihan Kartu Kredit Macet Yang Dilakukan Melalui Jasa Debt Collector (Studi Di Pt. Bank Permata Tbk Cabang Slamet Riyadi Surakarta), Diss, (Universitas Sebelas Maret (UNS) Solo, 2013).

JAMMIAH (Jurnal Ilmiah Mahasiswa Ekonomi Syariah), Volume 1, Nomor 1, Maret 2021 
Lapangan. Kartu Kredit Bank BRI terdiri memiliki beberapa jenis sesuai kebutuhan Nasabah, dan terdapat seperti 1) syarat-syarat yang harus dipenuhi bagi Nasabah, 2) Cara Pembayaran Kartu Kredit, serta 3) Hambatan yang dialami dalam Hal Kartu Kredit. ${ }^{13}$

Adapun hasil dan pembahasan mengenai langkah prosedur yang digunakan peneliti untuk menyelesaikannya yaitu dengan cara deskcall atau peneliti mendapatkan account yang diberikan oleh perusahaan, peneliti mendapatkan 4 nomor telepon antara lain nomor pribadi nasabah, nomor telepon rumah, nomor kantor dan nomor emergency contact. Jika semua nomor valid atau terhubung deskcall tidak perlu mencari tau lagi nomor nasabah, jika nomor telepon nasabah tidak valid, deskcall akan mencari tau melalui media sosial, karena account yang diberikan oleh perusahaan rata-rata data yang sudah pernah di hubungi pihak bank sebelumnya ${ }^{14}$.

Jika deskcall sudah valid dengan nasabah hal yang harus ditanyakan deskcall terhadap nasabah yaitu apakah nasabah masih di alamat rumah yang sama, apakah nasabah masih bekerja di tempat kerja yang sama, dan apakah nasabah berkomunikasi dengan emergency contact. Jika semua pertanyaan sudah disampaikan dan mendapatka hasil dari diskusi dengan nasabah deskcall diharapkan menginput datanya segera.

\section{A. Cara penanganan nasabah bermasalah}

Hasil dan pembahasan peneliti mengenai penanganan PT. Muara Toba Persada adalah dengan melakukan negosiasi dengan cara menagih tagihan kartu kredit melalui Telepon, Surat Peringatan (Letter), Kunjungan (Visit). Jika upaya hukum non litigasi tersebut tidak dapat terlaksana dengan baik maka pihak bank dapat menempuh upaya hukum litigasi penyelesaian sengketa melalui jalur pengadilan akan tetapi hal ini tidak dilakukan, mengingat jumlah tagihan kartu kreditnya lebih sedikit daripada jumlah pengeluaran yang dilakukan untuk melakukan menyelesaian sengketa melalui jalur pengadilan.

\section{B. Cara Pembayaran Kartu Kredit Bank BRI}

Saat ini kartu kredit BRI memberikan kemudahan bagi anda pemegang kartu kredit BRI dalam melakukan pembayaran selain pembayaran melalui ATM BRI, sehingga ada terhindar dari keterlambatan pembayaran. Bekerja sama dengan ATM Prima

${ }^{13}$ Ratu Desta, Analisis Pembiayaan Arrum Bpkb Dalam Meningkatkan Pendapatan Nasabah Pegadaian Syariah Menurut Perspektif Ekonomi Islam (Studi Pada PT Pegadaian Syariah Cabang Raden Intan Bandar Lampung), Diss, (UIN Raden Intan Lampung, 2018).

${ }_{14}$ Munir Fuady, Hukum Perkreditan Kontemporer, (Jakarta: Citra Aditya Bakti, 2006), 21-28.

JAMMIAH (Jurnal Ilmiah Mahasiswa Ekonomi Syariah), Volume 1, Nomor 1, Maret 2021 
dan jaringan ATM Bersama, pembayaran tagihan transaksi kartu kredit BRI akan sangat mudah, bisa di ATM mana saja dan kapan saja ${ }^{15}$.

Langkah-langkah pembayaran Kartu Kredit BRI seperti berikut :

1. Jaringan ATM BRI

Jika memiliki rekening Tabungan BRI, Anda dapat melakukan pembayaran melalui ATM BRI dimanapun Anda berada.

a. Pilih menu Transaksi Lain

b. Pilih menu Pembayaran

c. Pilih menu Kartu Kredit/KTA

d. Pilih menu BRI

e. Masukkan 16 angka Nomor Kartu Kredit

f. Pilih Ya, pada menu untuk melanjutkan transaksi

g. Masukkan jumlah pembayaran yang Anda inginkan

h. Pilih Ya, pada menu konfirmasi pembayaran

2. Jaringan ATM Bersama

Bagi Nasabah dari bank lain yang masuk dalam jaringan ATM Bersama, Anda dapat melakukan pembayaran melalui Jaringan ATM Bersama:

a. Pilih menu Transaksi Lainnya

b. Pilih menu Transfer/Pemindahan Dana

c. Pilih menu Kode Bank and 16 angka nomor Kartu Kredit BRI. (kode Bank BRI: 002)

d. Masukkan jumlah pembayaran yang Anda inginkan

e. Masukkan nomor referensi Transfer Anda, jika tidak perlu pilih Ya/Benar

f. Pilih sumber dana pembayaran

g. Pilih Ya/Benar, pada menu konfirmasi pembayaran

h. Biaya transfer pembayaran sebesar Rp. 6.500,- Member ATM Bersama.

3. Jaringan ATM Prima

Bagi Nasabah dari bank lain yang masuk dalam jaringan ATM Prima, Anda dapat melakukan pembayaran melalui Jaringan ATM Prima:

a. Pilih menu Transfer

b. Pilih menu ke Rekening Bank Lain

c. Masukkan Kode Bank (kode Bank BRI: 002)

d. Masukkan jumlah pembayaran yang Anda inginkan

e. Masukkan 16 angka Nomor Kartu Kredit BRI

f. Pilih Sumber dana pembayaran

${ }^{15}$ Alif Fathul Azmi Salabi, Perancangan Informasi Bijak Menggunakan Kartu Kredit Melalui Media Buku Panduan, Diss, (Universitas Komputer Indonesia, 2020).

JAMMIAH (Jurnal Ilmiah Mahasiswa Ekonomi Syariah), Volume 1, Nomor 1, Maret 2021

http://journal.sties-purwakarta.ac.id/index.php/jammiah/

ISSN: xxxx-xxxx (Media Online) xxxx-xxxx (Media Cetak) 
g. Pilih Benar, pada menu konfirmasi pembayaran

h. Biaya transfer pembayaran sebesar Rp. 6.500,-

4. Transfer Antar Bank

Jika akan melakukan pembayaran tagihan Kartu Kredit BRI dengan jumlah besar (yang tidak dapat dilakukan melalui ATM), bisa menggunakan transfer ntar bank yang ditujukan ke No. Rek 022901000857998 - Rekening Titipan Transfer Kartu Kredit BRI, cukup mencantumkan nama dan nomor Kartu Kredit BRI Anda pada kolom berita.

5. SMS Banking

SMS Banking adalah layanan yang memungkinkan Anda yang dinamis dan seringkali tak sempat untuk ke ATM atau bank, untuk melakukan transaksi perbankan melalui media SMS. Manfaatkan fasilitas SMS Banking yang mudah, cepat dan hemat waktu untuk melakukan pembayaran Kartu Kredit BRI Anda, dengan cara:

a. Melakukan registrasi di ATM BRI Cara registrasi SMS Banking:

1) Masukkan kartu ATM

2) Masukkan PIN ATM

3) Pilih menu Transaksi Lain

4) Pilih Registrasi

5) Pilih Registrasi SMS Banking

6) Masukkan nomor HP yang Anda gunakan untuk aplikasi ini

7) Masukkan nomor PIN Anda

8) Kembali Masukkan nomor PIN Anda

9) Nasabah menerima struk ATM

Setelah melakukan registrasi di ATM BRI, maka selanjutnya Anda dapat mendatangi Unit Kerja BRI terdekat untuk mendapatkan aplikasi tersebut.

b. Pembayaran Kartu Kredit BRI Visa:

1) Pada SMS Banking bermenu, pilih menu SMS Payment

2) Kemudian pilih menu K. Kredit/KTA

3) Kemudian Pilih BRI

4) Masukkan data yaitu Nomor Kartu Kredit danJumlah Pembayaran.

6. Internet Banking

Manfaatkan fasilitas Internet Banking yang semakin memudahkan Anda dalam melakukan setiap pembayaran tagihan kartu kredit Anda. Syarat menggunakan layanan Internet Banking BRI :

a. Merupakan nasabah BRI (BritAma/Simpedes/Giro Berkartu)

b. Memakai simcard di telepon genggam, yang bekerjasama dengan BRI 
c. Melakukan registrasi non finansial di ATM/Mini ATM BRI dan registrasi finansial di Unit Kerja BRI.

Adapun beberapa contoh kartu kredit BRI sebagai berikut :

Gambar 1

Kartu Kredit Bank BRI Wonderful Indonesia

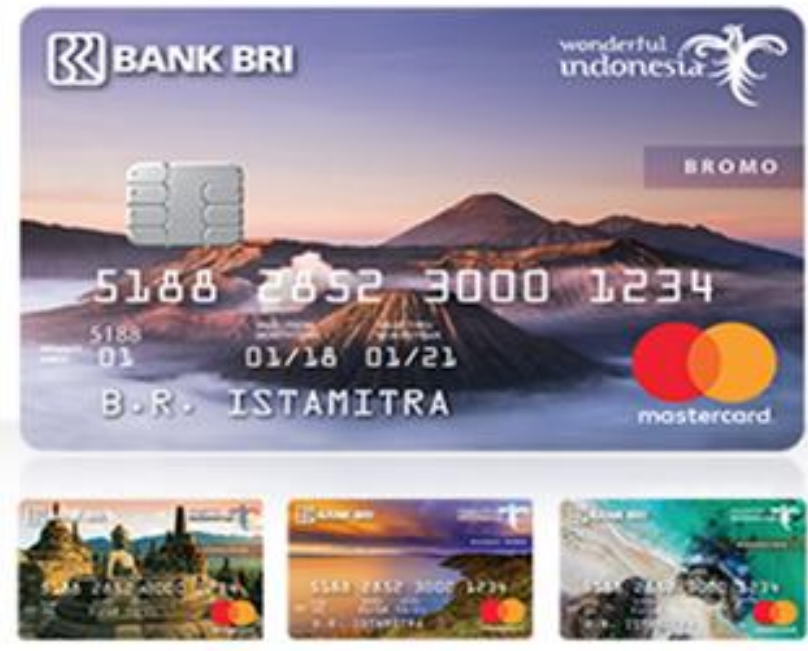

Merupakan Kartu Kredit Co-Branding yang diterbitkan oleh BRI bekerjasama dengan Kementrian Pariwisata Republik Indonesia, diberikan kepada individu yang ingin menikmati keindahan alam dan budaya Indonesia.

1. Benefit/fitur unggulan:

a. 2x BRI Point setiap transaksi di MCC Travel, Hotel dan Airlines

b. Poin Reward

2. Persyaratan khusus:

a. Usia 25-55 Tahun

b. Minimal Penghasilan Rp. 10.000.000,-

3. Limit:

a. Rp. 15.000.000,- sampai dengan Rp. 75.000.000,-

\section{Gambar 2}

Kartu Kredit Bank BRI World Access

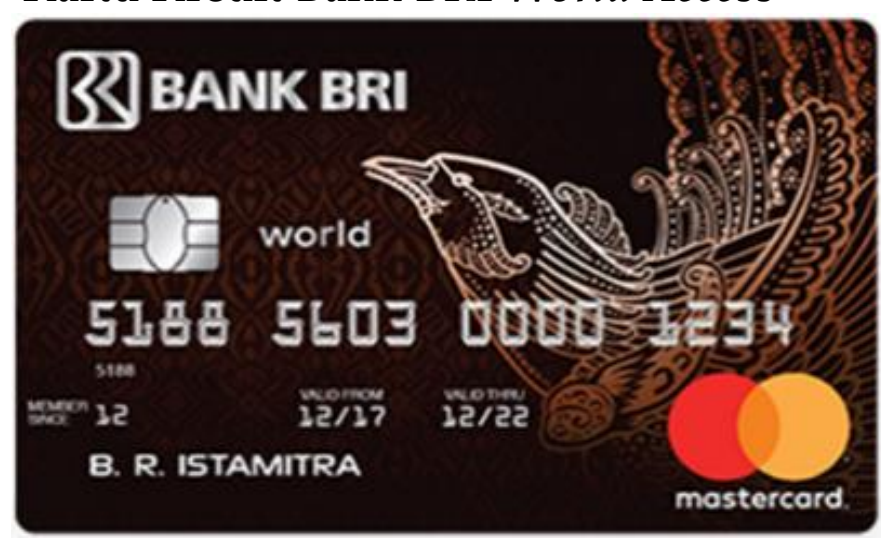

JAMMIAH (Jurnal Ilmiah Mahasiswa Ekonomi Syariah), Volume 1, Nomor 1, Maret 2021

http://journal.sties-purwakarta.ac.id/index.php/jammiah/

ISSN: xxxx-xxxx (Media Online) xxxx-xxxx (Media Cetak) 
1. Benefit/fitur unggulan:

a. 2x BRI Point setiap transaksi di MCC Travel, Hotel dan Airlines Double Mileage Convertion untuk setiap BRI Point pada maskapai yang telah bekerjasama.

b. Penghasilan Rp. 30.000.000,-

2. Limit: Persyaratan khusus:

c. Usia 25-55 Tahun

3. Minimal

a. Rp. 50.000.000,- sampai dengan Rp. 999.000.000,-

\section{Gambar 3}

\section{Kartu Kredit Bank BRI Business Card}

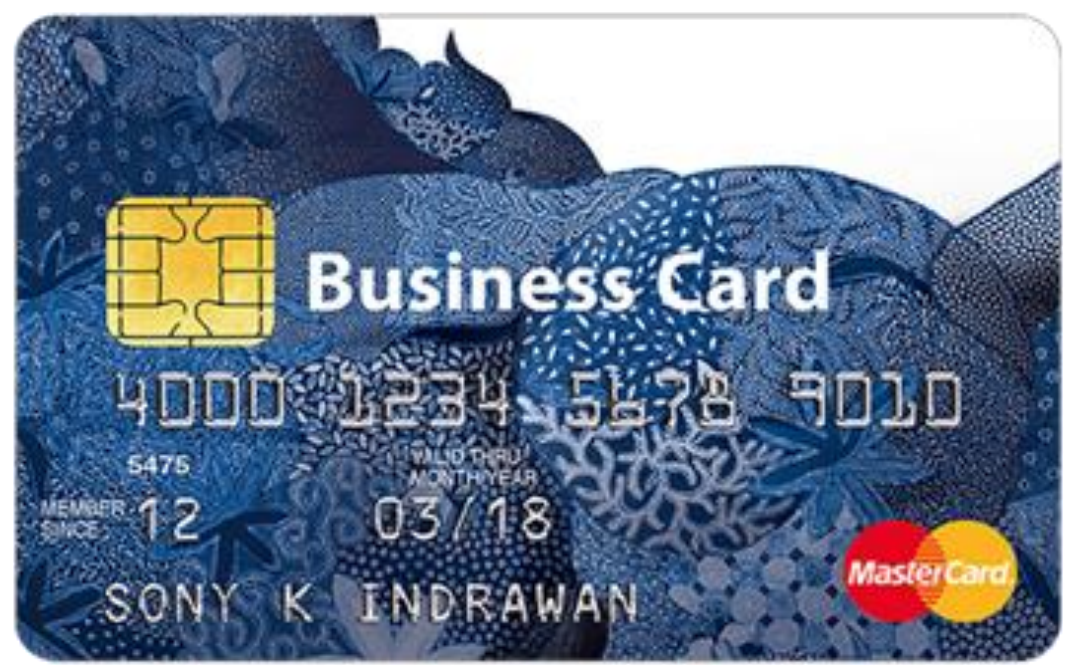

Merupakan Kartu Kredit yang diterbitkan oleh BRI kepada karyawan dalam satu perusahaan yang telah bekerjasama dengan Bank BRI untuk memudahkan transaksi sehari-hari (baik transaksi di EDC, online, maupun tarik tunai di ATM).

1. Benefit/fitur unggulan:

a. Free Annual Fee For Life

b. Gratis ex-lounge

2. Persyaratan khusus:
a. Usia 25-55 Tahun

3. Limit:

a. Mulai Dari Rp. 5.000.000,-16

${ }^{16}$ Safitri Kartika Dewi, Prosedur Pelaksanaan Produk Tabungan Britama Edisi Anak Muda Pada PT. Bank Rakyat Indonesia (Persero), Tbk. Kantor Cabang Panglima Polim, Diss, (Universitas Pembangunan Nasional Veteran Jakarta, 2019).

JAMMIAH (Jurnal Ilmiah Mahasiswa Ekonomi Syariah), Volume 1, Nomor 1, Maret 2021 


\section{KESIMPULAN}

Dalam penanganan deskcall terhadap nasabah harus melakukan pencarian data terbaru dikarnakan data yang diberikan perusahaan rata-rata data yang sudah pernah dikelola oleh bank BRI, oleh karena itu deskcall harus lebih teliti terhadap pencarian data terbaru nasabah.

Faktor yang menyebabkan nasabah masuk kolektibilitas lima di PT. Muara Toba Persada yaitu karena tidak adanya itikad baik dari pemegang kartu kredit, karena adanya kebutuhan lain yang mendesak, dan karena pemegang kartu kredit di PHK. Dengan demikian Hasil dan pembahasan peneliti mengenai penanganan PT. Muara Toba Persada adalah dengan melakukan negosiasi dengan cara menagih tagihan kartu kredit melalui Telepon, Surat Peringatan (Letter), Kunjungan (Visit). Jika upaya hukum non litigasi tersebut tidak dapat terlaksana dengan baik maka pihak bank dapat menempuh upaya hukum litigasi penyelesaian sengketa melalui jalur pengadilan akan tetapi hal ini tidak dilakukan, mengingat jumlah tagihan kartu kreditnya lebih sedikit daripada jumlah pengeluaran yang dilakukan untuk melakukan menyelesaian sengketa melalui jalur pengadilan.

Dalam menggunakan kartu kredit sebaiknya pemegang kartu kredit harus lebih cermat dalam melunasi tagihan kartu kreditnya dengan memenuhi ketentuan yang telah diperjanjikan sebelumnya sehingga tidak timbulnya tagihan kartu kredit wanprestasi, dan untuk pihak PT Bank Mandiri (Persero) Tbk Gajah Mada Denpasar selaku penerbit kartu kredit sebaiknya lebih meningkatkan kinerjanya dalam melakukan analisa terhadap calon pemegang kartu kredit, tidak hanya semata-mata mencari keuntungan yang nantinya hanya akan menimbulkan kartu kredit wanprestasi di kemudian hari.

\section{DAFTAR PUSTAKA}

Departemen Pendidikan dan Kebudayaan, Kamus Besar Bahasa Indonesia, Jakarta: Departemen Pendidikan dan Kebudayaan, 1985.

Dewi, Safitri Kartika, Prosedur Pelaksanaan Produk Tabungan Britama Edisi Anak Muda Pada PT. Bank Rakyat Indonesia (Persero), Tbk. Kantor Cabang Panglima Polim, Diss, Universitas Pembangunan Nasional Veteran Jakarta, 2019.

Fuady, Munir, Hukum Perkreditan Kontemporer, Jakarta: Citra Aditya Bakti, 2006. Hardjo, Wahyu, Kartu Kredit dalam Kaitannya dengan Sistem Pembayaran, Jakarta: Pro Justitia, 1992.

Hartono, Sri Redjeki, Aspek Hukum Penggunaan Kartu Kredit, Jakarta: Badan Pembinaan Hukum Nasional, Departemen Kehakiman, 1994.

Mahmoedin, 100 Penyebab Kredit Macet, Jakarta: Pustaka Sinar Harapan, 1995.

JAMMIAH (Jurnal Ilmiah Mahasiswa Ekonomi Syariah), Volume 1, Nomor 1, Maret 2021 
Mahmoedin, 100 Penyebab Kredit Macet, Jakarta: Pustaka Sinar Harapan, 1995.

Putra, I Made Tistiawan Dwihara, dkk, Analisis Sistem Penyaluran Kredit Pada Badan Usaha Milik Desa (Bumdes) Muncul Sari Aji Desa Sudaji, Kecamatan Sawan, Kabupaten Buleleng, Jurnal S1 Akuntasi Universitas Pendidikan Ganesha, Volume 8 No. 2, 2017

Ramadhani, Febry Ayu, Analisis penanganan pembiayaan bermasalah nasabah usaha mikro: Studi kasus pada Bank Syariah Mandiri KCP Kepanjen. Diss, Universitas Islam Negeri Maulana Malik Ibrahim, Malang, 2019.

Salabi, Alif Fathul Azmi, Perancangan Informasi Bijak Menggunakan Kartu Kredit Melalui Media Buku Panduan, Diss, Universitas Komputer Indonesia, 2020.

Saputri, Leni, Penanganan pembiayaan bermasalah berdasarkan 5 kolektibilitas di bank syari'ah mandiri (bsm) kcp banjarnegara, Diss, Institut Agama Islam Negeri (IAIN) Bandung, 2015.

Susilo, Edi, Analisis Pembiayaan Dan Risiko Perbankan Syariah Jilid 1, Yogyakarta: Pustaka Pelajar, 2017.

Utomo, Setiawan Budi, Hukum Kartu Kredit Syariah, Bandung: Rajawali Pers, 2009.

Winarto, Gesha Tri, Evaluasi Sistem Pemberian Dan Pelunasan Kredit Pada Koperasi Harum Desa Kunira Kecamatan Batangan Kabupaten Pati, Diss, Universitas Sebelas Maret (UNS) Solo, 2010. 